\title{
Impact and distribution of bottom trawl fishing on mud-bottom communities in the Kattegat
}

Pommer, Christina Dahl; Olesen, Michael; Hansen, Jorgen L. S.

Published in:

Marine Ecology - Progress Series

Link to article, DOI:

$10.3354 /$ meps 11649

Publication date:

2016

Document Version

Publisher's PDF, also known as Version of record

Link back to DTU Orbit

Citation (APA):

Pommer, C. D., Olesen, M., \& Hansen, J. L. S. (2016). Impact and distribution of bottom trawl fishing on mudbottom communities in the Kattegat. Marine Ecology - Progress Series, 548, 47-60.

https://doi.org/10.3354/meps11649

\section{General rights}

Copyright and moral rights for the publications made accessible in the public portal are retained by the authors and/or other copyright owners and it is a condition of accessing publications that users recognise and abide by the legal requirements associated with these rights.

- Users may download and print one copy of any publication from the public portal for the purpose of private study or research.

- You may not further distribute the material or use it for any profit-making activity or commercial gain

- You may freely distribute the URL identifying the publication in the public portal 


\title{
Impact and distribution of bottom trawl fishing on mud-bottom communities in the Kattegat
}

\author{
Christina D. Pommer ${ }^{1,3, *}$, Michael Olesen ${ }^{1,4}$, Jørgen L. S. Hansen ${ }^{2}$ \\ ${ }^{1}$ University of Copenhagen, Department of Biology, Strandpromenaden 5, 3000 Helsingør, Denmark \\ ${ }^{2}$ Aarhus University, Department of Bioscience, Frederiksborgvej 399, 4000 Roskilde, Denmark \\ ${ }^{3}$ Present address: DTU-Aqua, Jægersborg Allé 1, 2900 Charlottenlund, Denmark \\ ${ }^{4}$ Present address: Rambøll, Hannemanns Allé 53, 2300 Copenhagen S, Denmark
}

\begin{abstract}
The Kattegat in the inner Danish waters has been trawled for at least $80 \mathrm{yr}$, but so far only few attempts have been made to quantify the trawl effort, its spatial distribution and its potential ecological impact on the benthic fauna. GIS-analyses of VMS-data from trawling in the Kattegat by both Danish (2005-2009) and Swedish (2007-2009) vessels show that $95 \%$ of all trawling occurs below $22 \mathrm{~m}$ depth. Most activity takes place on homogeneous benthic habitats with muddy sediment at depths below the halocline and with almost the same salinity across the entire area. Furthermore, the estimate of trawled area demonstrated that the habitats are nearly $100 \%$ impacted, and frequencies of trawling beneath $100 \mathrm{~m}$ depth can reach 20 events per year. Multivariate analysis of community composition could not discriminate between lightly trawled and heavily trawled areas. However, a strong habitat selectivity of the trawl activity and inter-correlation between trawl activity and depth-related community structures complicated interpretation of the results. Species with biological traits previously categorized as sensitive to physical disturbance showed higher abundance in areas with low trawl activity compared to areas with higher activity. Thus, the Kattegat has been impacted to an extent where areas with reference conditions for certain habitats below $22 \mathrm{~m}$ no longer exist. Consequently, it is unknown how the benthic communities would have appeared without trawl disturbance and, thus, difficult to determine the impact of continued disturbance.
\end{abstract}

KEY WORDS: Trawl impact $\cdot$ Physical disturbance $\cdot$ Benthic community $\cdot$ Soft-bottom $\cdot$ Kattegat Habitat degradation $\cdot$ Biological traits $\cdot$ Vessel Monitoring Systems

- Resale or republication not permitted without written consent of the publisher

\section{INTRODUCTION}

Bottom trawling significantly impacts benthic marine ecosystems worldwide (Jones 1992, Thrush \& Dayton 2002, Hiscock \& Tyler-Walters 2006, Hinz et al. 2009, Bradshaw et al. 2012, van Denderen et al. 2014, Johnson et al. 2015). Considering the global extent of bottom trawling, it is essential to understand the impact of trawling on benthic habitats in all regions (Kaiser et al. 2006). In Denmark, bottom trawling with otter trawls started in the early 1900s (Blegvad 1946). However, the geographical distribution of trawling in Danish waters has largely remained un- known or has been too difficult to quantify with sufficient spatial resolution to identify preferred trawl areas, i.e. habitats with similar temperature, depth, salinity and sediment that are specifically targeted by trawl fisheries and to match trawling with available benthos sampling programs. With the introduction of satellite surveillance (Vessel Monitoring Systems [VMS]) in 2005, high-resolution information about the distribution of bottom trawling became available. Combined with benthic fauna monitoring data, this information provides a unique opportunity to study trawl effects on benthic fauna, as recently demonstrated in the North Sea (van Denderen et al. 2014). 
Bottom trawl fishing in the sea has been compared to forest clear cutting, because it is highly indiscriminate and sweeps up everything in its path, relocating even large rocks and boulders (Watling \& Norse 1998, Auster \& Langton 1999). This physical alteration homogenizes and changes habitats, as suitable hard substrates for sessile epibiota are removed (Jones 1992, Hall 1994). Diminishing the structural complexity of the habitats may reduce the biodiversity (Huston 1998, Hewitt et al. 2005, Griffin et al. 2009). On soft sediments, trawling may cause habitat changes due to alteration of sediment redox profiles and resurfacing of potentially toxic substances (Bradshaw et al. 2012) buried in deeper anoxic sediment layers (Kaiser et al. 2002). In addition, ploughing and scraping activities of trawling cause sediment resuspension (Jones 1992). In sheltered areas (e.g. deep areas), where resuspension seldom occurs from natural causes (such as storm events), and where faunal communities may not be adapted to sediment resuspension, this kind of physical disturbance may have a negative effect on epibenthic filter feeders (Caddy 1973). For example, Floderus \& Pihl (1990) found that resuspension due to trawling in the deeper part of the Kattegat was similar to that of wind-induced disturbance in shallow coastal waters.

Short-term negative effects of trawling include direct damage to benthic fauna as well as capture of non-target species (Collie et al. 1997). Trophic structures of the benthic food web may change because damaged or relocated fauna left on the sediment surface are exposed to predators (Groenewold \& Fonds 2000). This sudden increase in available food favors scavengers, which increase their abundance in response to trawling (Ramsay et al. 1998). All together, these impacts change the composition of the faunal community (e.g. Auster \& Langton 1999, Kaiser et al. 2002, Hinz et al. 2009).

Long-term effects of trawling have been difficult to document due to lack of comparable reference conditions (Dayton et al. 1998, Handley et al. 2014). Nevertheless, some studies have shown long-term effects of trawling in terms of community changes going from large colony forming epifauna and large bioturbating infauna to small, deposit feeding polychaetes and scavenging epifauna (e.g. Norse \& Watling 1999, Tillin et al. 2006, Hinz et al. 2009, Mangano et al. 2014).

Recent studies of long-term impacts on faunal communities focused on changes in functional diversity. Species with certain biological traits, e.g. large body size, low dispersal potential, late maturation and long lifespan, have been proposed to be relatively more sensitive to physical disturbance (Bremner et al. 2003, 2005). Likewise, sessile species and species that live near the trawl-exposed sediment surface will be more vulnerable than deep-burrowing or mobile species. In particular, the structuring fauna, e.g. upright, tube-building or reef-forming species, seem vulnerable to trawling (Hixon \& Tissot 2007, Wilding 2011). Together with burrowing species, these faunal components add structural complexity to otherwise unstructured, flat and featureless soft sediment habitats and are essential for maintaining biodiversity and ecosystem functions (Widdicombe \& Austen 1998, Bradshaw et al. 2003). As a result, fauna destruction due to trawling affects specific ecosystem functions, and these effects may be amplified in the soft-sediment habitat where the fauna is less adapted to physical pressure due to the low natural disturbance on mud bottoms (Thrush \& Dayton 2002, Thrush et al. 2006).

Effects of bottom trawl fishery on benthic biota have been studied in the North Sea (e.g. de Groot 1984, Hiddink et al. 2006, Callaway et al. 2007, Robinson \& Frid 2008), the Baltic Sea (e.g. Rumohr \& Krost 1991, Ziegler et al. 2003), the Irish Sea (e.g. Kaiser \& Spencer 1996, Hinz et al. 2009), the Mediterranean (Rosenberg et al. 2003, de Juan et al. 2009) and the Pacific Ocean (e.g. Thrush et al. 1998, Cryer et al. 2002). Although the Kattegat, located between the Baltic Sea and the North Sea, has been trawled intensively for nearly a century, the impact of the Danish demersal fishery on the benthos has not been studied. A study of the Swedish bottom trawl fishery in the Kattegat have documented increased resuspension (Floderus \& Pihl 1990), while Nilsson \& Ziegler (2007) related the effect of fishing directly to sea floor habitats. Both of these studies used Swedish logbook records, which include both data on landings and hours of active trawling, to estimate the effort in ICES squares of $30 \times 30$ nautical miles (nmi) and grids of $5 \times 5 \mathrm{~km}^{2}$, respectively. Nilsson \& Ziegler (2007) found that the trawl frequencies exceed the indicated recovery time for benthic communities on a substantial part of the muddy habitats, which were therefore permanently altered. However, due to low spatial resolution of the trawling data, the trawling activity could not be linked to benthic community structure.

In the present study, we determined the spatial distribution of bottom trawl fishery on soft-bottom habitats in the Kattegat by analyzing high-resolution VMS-data of both Danish and Swedish trawl vessels during 2005-2009 and 2007-2009, respectively. We studied the impact of this fishery method on benthic invertebrate communities by including correspon- 
ding time series of benthic faunal data. The community composition along trawl and environmental gradients was analyzed with special emphasis on distribution of biological traits previously defined to be sensitive to trawling. We tested the hypothesis that species community compositions have changed and can be traced along a gradient of trawl intensities.

\section{MATERIALS AND METHODS}

\section{Study area}

Data were collected from the Kattegat (Fig. 1a), which is a shallow sea ( $<150 \mathrm{~m}$ deep), characterized by an estuarine circulation pattern with inflow (toward the Baltic Sea) of high saline bottom water from the North Sea and brackish out-flowing surface water from the Baltic Sea. A halocline persists all year round throughout the area. Salinity in the surface layer $(<15 \mathrm{~m})$ is between $10-20$ in the southern Kattegat and 33 in the northern region closest to the Skagerrak and the North Sea. Beneath the halocline, similar conditions in salinity and temperature persist throughout the Kattegat basin.

The Kattegat has a total area of approximately $22000 \mathrm{~km}^{2}$ and an average depth of about $27 \mathrm{~m}$. The western part is mainly a shallow area with depths down to 10-20 m, whereas the eastern part generally has depths between 20 and $60 \mathrm{~m}$, with deep channels down to $150 \mathrm{~m}$ (Paulomäki et al. 2008). The sediment in the western part of the Kattegat is mainly composed of sand, while the eastern areas (30-50 m) consist of mud (Fig. 2).

The Kattegat is connected to the Baltic Sea through narrow straits, but has a large opening in the north
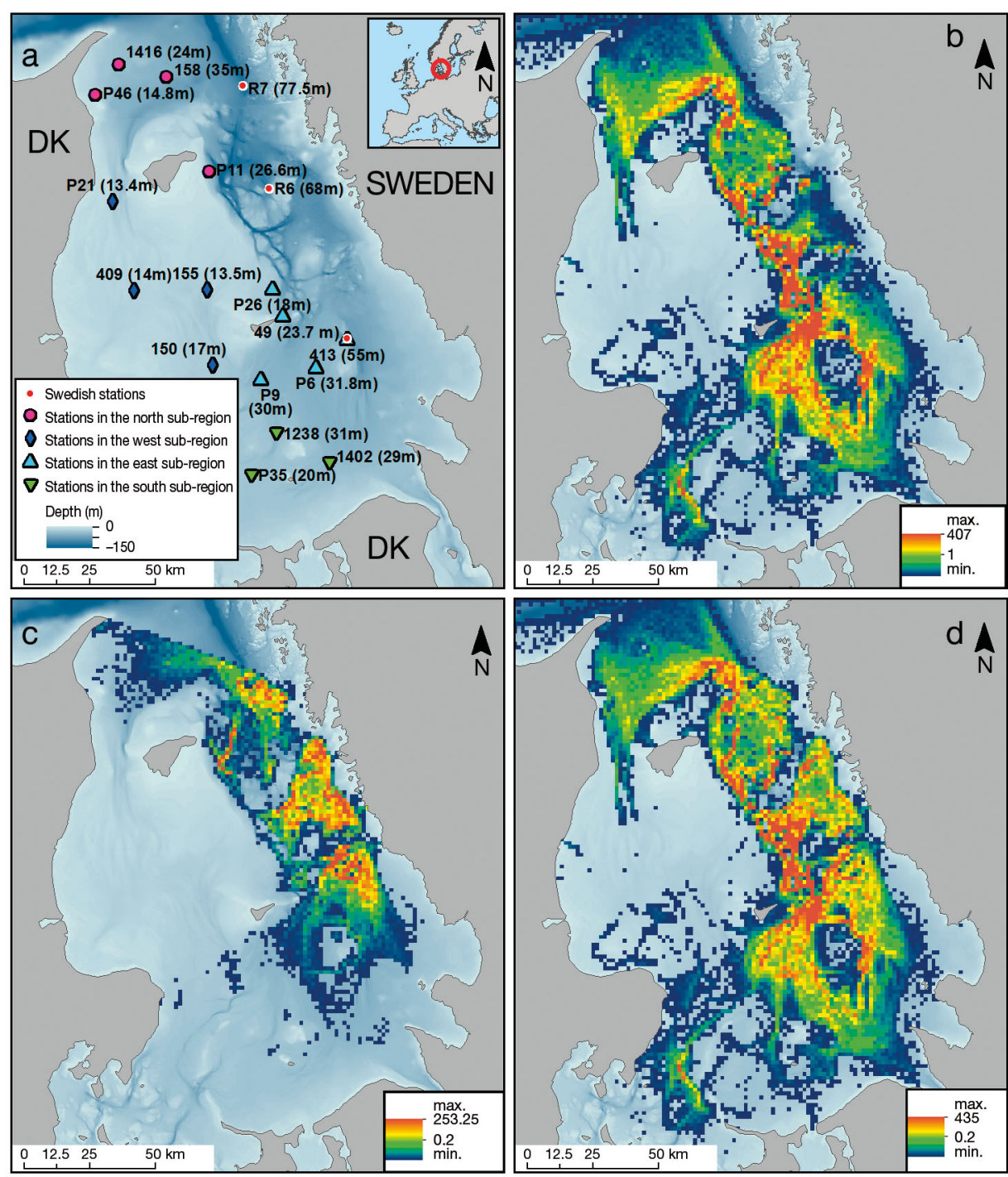

Fig. 1. (a) Location of benthic sample stations in the Kattegat, identified with both name and water depth. Blue shading: bathymetry. (b) Distribution of total Danish bottom trawl activity (2005-2009), showing which areas were most intensively trawled. (c) As in (b) but for total Swedish bottom trawl activity (2007-2009). (d) As in (b) but for data from (b) and (c) combined. DK = Denmark 


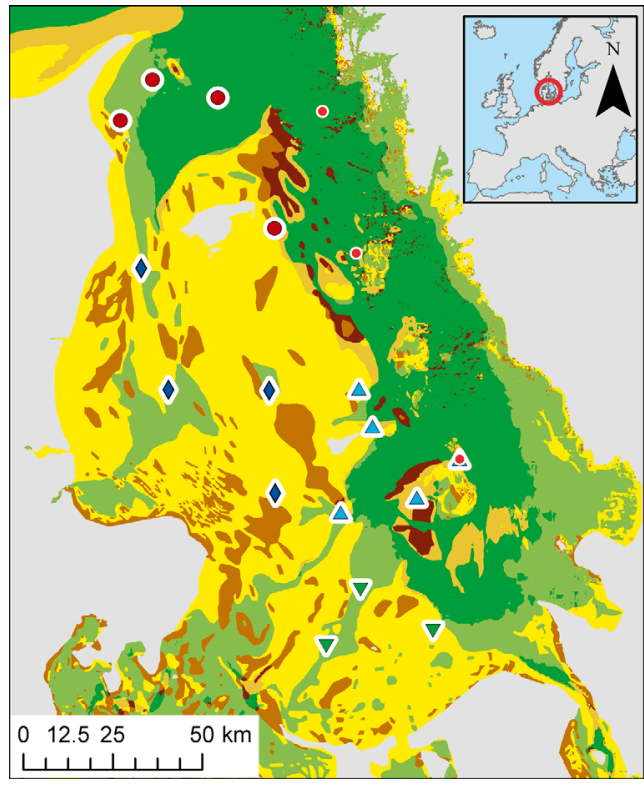

- Swedish stations

Stations in the west sub-region

$\nabla$ Stations in the south sub-region

- Stations in the north sub-region

$\Delta$ Stations in the east sub-region

Sediment

Non-photic hard bottom

Photic hard bottom

Non-photic mud and clay

Photic mud and clay

Non-photic sand

Photic sand gear used by the vessel, while the speed was used to classify whether the vessel was fishing or steaming. The data used in our study were thus obtained from all the demersal gear types and from VMS points where the speed was between 2 and $4 \mathrm{nmi}$ $\mathrm{h}^{-1}$ (mean: $5.6 \mathrm{~km} \mathrm{~h}^{-1}$ ) for Danish vessels and between 0.5 and $3.5 \mathrm{nmi} \mathrm{h}^{-1}$ (mean: $3.7 \mathrm{~km} \mathrm{~h}^{-1}$ ) for Swedish vessels.

Because the VMS registers a signal once an hour, we assumed that the vessels being registered had been doing the same activity for the past hour and, thus, converted VMS to hours trawled. All VMS data were projected to 'UTM 32' with datum 'ETRS 1989'. Data from Danish VMS monitoring were available for the years 2005 to 2009 as grid-files with a cell size of $1500 \times 1500 \mathrm{~m}$, each cell with a pixel value representing a number of VMS-points (DTU-Aqua 2010). The Swedish data from 2007 to 2009 were available as shape-files, complete with UTM-coordinates and Trip-ID (Swedish Board of Fisheries 2010). In order to make an assessment of the overall bottom trawl activities in the Kattegat, the Swedish data were converted to grid-files with the same cell size and grid as the Danish data.

The benthic faunal data were obtained from the national Danish monitoring program (Aarhus University 2010) and Swedish monitoring programs (Naturvårdsverket 2010) in the Kattegat. The Danish sampling program has collected samples from 1994 onwards in the mid- and western parts of the Kattegat (Fig. 1a) with a Haps corer (sampled area of 0.0143 $\mathrm{m}^{2}$; Kanneworff \& Nicolaisen 1972) in spring (April-May), using 5 replicates per station. Data from 16 stations were used in the present study. At each station, the 5 samples obtained per year were pooled (235 in total, since samples from 1998 were not included due to unusually low sampling effort) to be comparable to the size of the Swedish samples (0.1 $\mathrm{m}^{2}$ ). Swedish data were available from 2000 to 2008 from 3 stations located in the eastern part of the Kattegat. The Swedish samples were collected with a Smith-McIntyre grab $\left(0.1 \mathrm{~m}^{2}\right)$ with 4 samples per station $(\mathrm{n}=108)$.

\section{Analyses}

The different GIS layers were aggregated in the program ArcGIS version 9.3.1 (ESRI 2009) to give a final output of Danish and Swedish trawl intensities mandatory log book made it possible to identify the
Data from the satellite-based VMS were used to monitoring programs, fishing vessels with a total length of more than $15 \mathrm{~m}$ are required to have a VMS system installed that sends boat ID, with data on position, time, speed and course, to the national fisheries management authorities once an hour (for further information, see Bastardie et al. 2010). Combining the vessel ID with information from the 
summarized as VMS points in a $1500 \times 1500 \mathrm{~m}$ grid. The area swept by trawling was estimated by multiplying the typical speed of the vessel during trawling with the width of the trawl gear for all VMS points identified as active trawling to give the total area swept in $\mathrm{km}^{2}$. The average speed for Swedish vessels was estimated to be $3.7 \mathrm{~km} \mathrm{~h}^{-1}$ and for Danish vessels $5.6 \mathrm{~km} \mathrm{~h}^{-1}$. The primary trawl gear used in the Kattegat area is a twin-trawl with a distance of 50 to $150 \mathrm{~m}$ between the 2 trawl doors (Eigaard et al. 2016). We considered 2 different trawl widths: 100 and $50 \mathrm{~m}$. The total distance between the trawl doors during fishing is $100 \mathrm{~m}$, which includes impacts from all parts of the gear with potential bottom contact (i.e. doors, sweeps, bridles, and footropes). However, as the sweeps and bridles may not be in direct contact with the bottom during trawling, the distance between the doors may overestimate impact of the gear (Nilsson \& Ziegler 2007). Earlier studies have suggested that the trawl doors and footrope cause the largest effect on the seafloor (Kaiser et al. 2002, Nilsson \& Ziegler 2007). Therefore, a more conservative value of $50 \mathrm{~m}$ was also considered, assumed to represent width of the track swept by the trawl doors and footropes during fishing. Consequently, each VMS-point of Danish and Swedish vessels corresponds to a total swept area of 0.19 and $0.28 \mathrm{~km}^{2}$, respectively, by assuming a gear width of $50 \mathrm{~m}$, and twice the area if the gear is assumed to be $100 \mathrm{~m}$ wide.

Benthic communities were analyzed by using the multivariate statistical program PRIMER 6 (Clarke \& Gorley 2006). First, a square root transformation was applied to all data in order to down-weigh highly dominant species. Next, the similarity of benthic assemblages was calculated using the Bray-Curtis similarity index (Bray \& Curtis 1957), and multidimensional scaling (MDS) plots were used to visualize the relation among sample similarities. SIMPER analysis was then applied in order to find discriminating species responsible for community differences, and the ANOSIM analysis was used to calculate significance values for differences between groups of data (Clarke 1993). Finally, the BIO-ENV procedure was applied to show how much of the observed biological pattern was explained by abiotic variables such as trawl intensity and water depth.

The mean abundance of sensitive species was compared among 3 Swedish stations in the trawled habitat. The selected species all possess biological traits that increase their sensitivity to the physical disturbance of trawling (Rumohr \& Kujawski 2000, Tillin et al. 2006, Greathead et al. 2007, Hixon \&
Tissot 2007, Olsgard et al. 2008). We selected sensitive species, which were characteristic and/or numerically dominant in the deep $(>22 \mathrm{~m})$ part of the Kattegat and with biological traits sensitive specifically to physical disturbance. It was assumed that the distribution of sensitive species below $22 \mathrm{~m}$ was not biased by depth as their theoretical depth range is defined in the literature to cover the entire depth in question (e.g. see BIOTIC database http:// www.marlin.ac.uk/biotic/).

\section{RESULTS}

\section{Trawling effort and spatial distribution}

In general, there were only minor differences between the effort distribution of the Danish and Swedish vessels over the time period studied. The highest activity for Danish vessels occurred in the mid-Kattegat along the deep channels and towards the east at the slopes around the 3 large shallow grounds (Fig. 1b). There was also considerable activity in the southwestern part of the Kattegat (at the entrance to the Belt Sea) and in the northern part of the Kattegat. However, a large shallow area with depths between 10 and $20 \mathrm{~m}$ was completely devoid of any trawl activity in the mid-western region. Most of the Swedish trawling took place within Swedish territorial waters (Fig. 1c). The highest trawl activity was found in the mid- and northern Kattegat. Combining Swedish and Danish data from the Kattegat shows that the activity is concentrated in the eastern deep part of the Kattegat (Fig. 1d). In particular, there is an intensive activity in the deep, eastern channels running from north to south, an area north of the island of Læsoe and in the southeast Kattegat on slopes around shallow grounds-the latter 2 areas were dominated by Danish activity.

The average annually trawled area by Danish vessels in the Kattegat during 2005-2009 was approximately $12000 \mathrm{~km}^{2} \mathrm{yr}^{-1}$, assuming an effective haul width of $50 \mathrm{~m}$, and $25000 \mathrm{~km}^{2} \mathrm{yr}^{-1}$, assuming a gear width of $100 \mathrm{~m}$. Corresponding values for the Swedish vessels were $4700 \mathrm{~km}^{2} \mathrm{yr}^{-1}$ and $10000 \mathrm{~km}^{2}$ $\mathrm{yr}^{-1}$, respectively. The total area affected by Danish and Swedish trawl fisheries in Kattegat was thereby $17000 \mathrm{~km}^{2} \mathrm{yr}^{-1}$ or $35000 \mathrm{~km}^{2} \mathrm{yr}^{-1}$, depending on the gear width. Although the Swedish effort is the smaller of the two, its spatial distribution is considerably more concentrated than the Danish and, thus, the main targeted areas in Swedish territorial waters are exposed to similar trawl disturbance. 


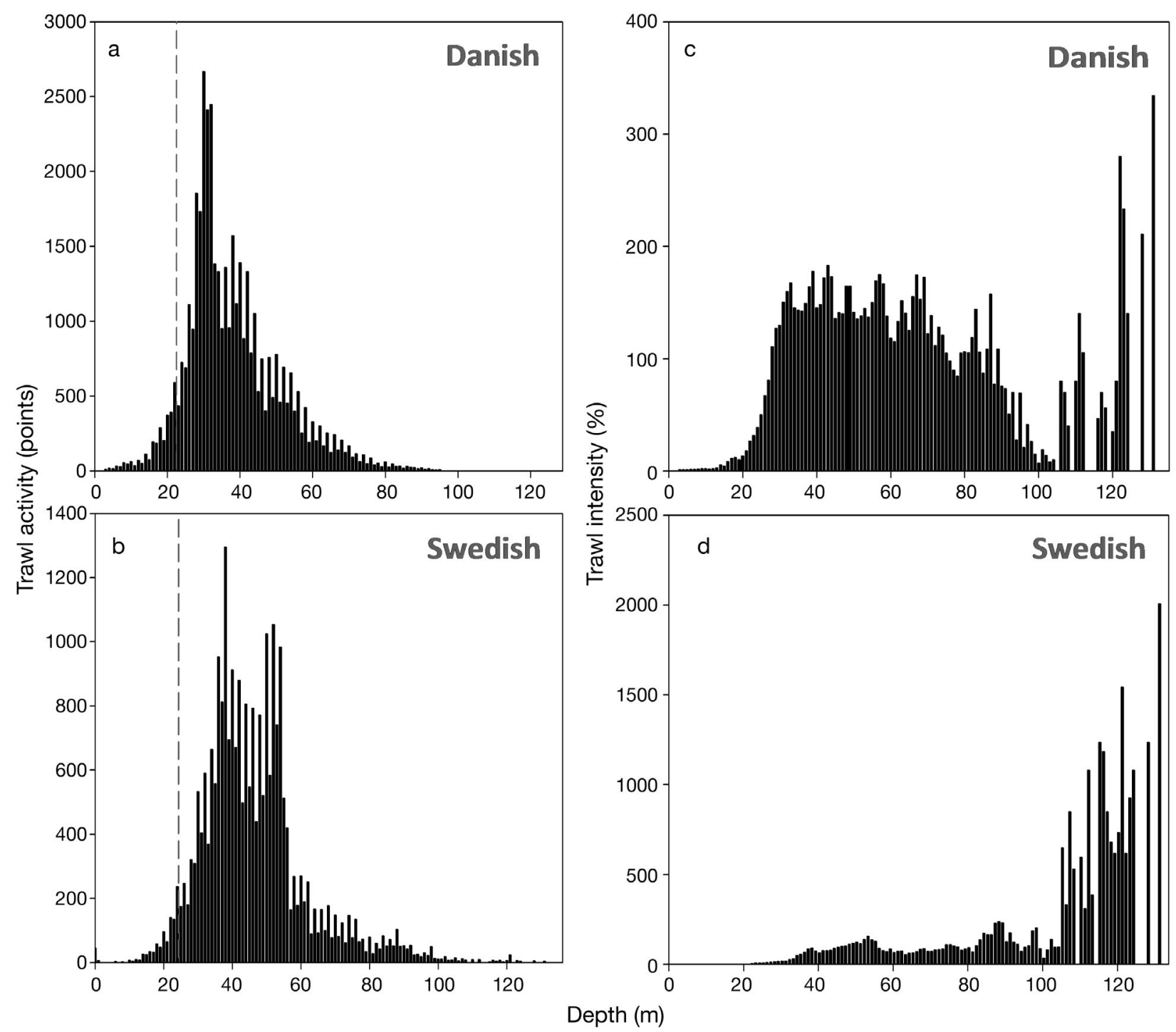

Fig. 3. (a) Average number of VMS points aggregated by depth (1 m interval) for Danish data from 2005 to 2009 . Gray dashed line: 95th percentile of the observations at depths $>22 \mathrm{~m}$. (b) As in (a) but for Swedish data from 2007 to 2009. (c) Average trawled area from 2005 to 2009 versus depth. Trawled area is shown as proportion (in \%) of the areal extent of each $1 \mathrm{~m}$ depth in the Kattegat by Danish vessels. Calculations assume a gear width of $0.05 \mathrm{~km}$ multiplied by the vessels' speed (mean: $5.6 \mathrm{~km}$ $\mathrm{h}^{-1}$ ). (d) As in (c) but for corresponding Swedish data from 2007 to 2009 . Average vessel speed was set to $3.7 \mathrm{~km} \mathrm{~h}^{-1}$. Note the differences in $y$-axis scales

\section{Distribution of trawling among benthic habitats}

The depth distribution of the VMS points (Fig. 3a) shows that Danish trawling mainly occurs in waters of 25 to $60 \mathrm{~m}$ depth, with a peak around $30 \mathrm{~m}$. The activity declines at depths below $60 \mathrm{~m}$ and is almost absent below $100 \mathrm{~m}$ depth. The vast majority of trawling (95\%) occurs below the halocline, and $<5 \%$ of the total trawling effort occurs at depths shallower than $22 \mathrm{~m}$. Thus, trawling is almost absent in the shallowest areas and, therefore, the shallowest $5 \%$ of the trawl effort (VMS points) has not been used to map trawl frequencies at depths less than $22 \mathrm{~m}$.
The Swedish effort is about $40 \%$ of the Danish and targets the same depth range, although slightly deeper fishing grounds are preferred (Fig. 3b). The activity peaks at $35 \mathrm{~m}$ and the majority of observations fall between 30 and $55 \mathrm{~m}$. Like the Danish trawling, $95 \%$ of Swedish trawling occurs in waters deeper than $22 \mathrm{~m}$.

Trawling intensity was quantified as the ratio of the area swept annually to the total area in each $1 \mathrm{~m}$ depth interval (i.e. trawl frequency per year). The depth range from 30 to $85 \mathrm{~m}$ is swept more than once per year by Danish trawlers. From 85 to $105 \mathrm{~m}$ there is a decrease in the Danish trawling intensity. The 
Swedish trawl intensity is less selective and covers the depth range 35-105 m more than 100\% annually.

Even though the deepest parts of the Kattegat (>100 m) cover a comparatively small area, it is relatively more disturbed by trawling, e.g. the Danish trawl intensity was up to 4 times greater at depths $>100 \mathrm{~m}$ (Fig. 3c). Swedish trawling showed even higher preferences for depths $>100 \mathrm{~m}$. In fact, the Swedish trawl intensity in the deepest parts can be 5 times the Danish effort at the same depths (Fig. 3d). Thus, the results show that all areas in the Kattegat deeper than $30 \mathrm{~m}$ are at least $100 \%$ directly impacted by trawl gear, and depths $>100$ m can be swept up to 20 times a year.

\section{Benthic communities}

The total number of taxonomic entities in the Danish samples was 621. There were 224 different polychaetes, 171 crustaceans, 70 bivalves, 58 in the category 'others', 54 gastropods, 27 echinoderms and 18 anthozoans. The most abundant polychaetes in the Swedish samples were Prionospio fallax, Scoloplos armiger and Pholoe inornata. Ampelisca tenuicornis, Balanus crenatus and Ampelisca brevicornis were the most abundant crustaceans. Other highly abundant species were the brittlestar Amphiura filiformis and the bivalves Kurtiella bidentata, Tellina fabula and Thyasira flexuosa. The sensitivity of the benthic community was estimated using AMBI (AZTI Marine Biotic Index), which divides the species into 5 ecological groups according to their sensitivity to disturbance (for further information on AMBI see Borja et al. 2000). The distributions of species in each group for the Danish data are shown in Table 1. The Swedish samples had a total of 392 taxonomical entities, of which 163 were polychaetes, 108 were crustaceans, 45 were bivalves (excl. gastropods), 28 were in the category 'others', 26 were gastropods, 18 were echinoderms and 8 were anthozoans. AMBI classification of species in the Swedish data is shown in Table 1.

In the Kattegat, the distribution of benthic communities was closely related to water depth, which was also a proxy for the bottom salinity due to the halocline at $15 \mathrm{~m}$ (Fig. 4a). Samples from the period 1994-2008 segregated into 2 distinct communities situated above and below $20 \mathrm{~m}$, which was also the border between brackish/occasional brackish environments and polyhaline environments. One 'shallow' $(14.8 \mathrm{~m})$ station (P46) grouped together with the 'deep' community instead of the shallow community
Table 1. Composition (based on abundance) of soft bottom macrofauna in 2008, according to their classification as AMBI (AZTI Marine Biotic Index) ecological group (based on their sensitivity to an increasing pollution gradient; for further explanation see Borja et al. 2000). Groups - I: species very sensitive; II: species indifferent; III: species tolerant; IV: second-order opportunistic species; V: first-order opportunistic species

\begin{tabular}{|c|c|c|c|c|c|}
\hline \multirow[t]{2}{*}{ Station } & \multirow{2}{*}{$\bar{I}$} & \multicolumn{4}{|c|}{ Macrofauna composition (\%) - } \\
\hline & & II & III & IV & $\mathrm{V}$ \\
\hline 42 & 53 & 25 & 8 & 0 & 14 \\
\hline 49 & 19 & 42 & 37 & 2 & 0 \\
\hline 1416 & 24 & 49 & 27 & 0 & 0 \\
\hline 1402 & 23 & 61 & 16 & 0 & 0 \\
\hline 155 & 47 & 25 & 23 & 5 & 0 \\
\hline 158 & 11 & 55 & 28 & 6 & 0 \\
\hline 409 & 22 & 51 & 22 & 2 & 3 \\
\hline $413^{\mathrm{a}}$ & 40 & 50 & 10 & 0 & 0 \\
\hline P11 & 18 & 58 & 21 & 3 & 0 \\
\hline P21 & 22 & 18 & 51 & 9 & 0 \\
\hline P26 & 47 & 27 & 24 & 2 & 0 \\
\hline P35 & 33 & 52 & 15 & 0 & 0 \\
\hline P46 & 25 & 38 & 30 & 7 & 0 \\
\hline P6 & 21 & 46 & 25 & 8 & 0 \\
\hline P9 & 25 & 43 & 25 & 4 & 4 \\
\hline $413^{\mathrm{b}}$ & 17 & 74 & 8 & 1 & 0 \\
\hline R6 & 10 & 81 & 8 & 2 & 0 \\
\hline R7 & 8 & 83 & 7 & 2 & 0 \\
\hline \multicolumn{6}{|c|}{${ }^{\mathrm{a} F r o m ~ D a n i s h ~ s a m p l e s ~(H a p s ~ c o r e r, ~} 0.0143 \mathrm{~m}^{2}$ ) } \\
\hline
\end{tabular}

(oval in Fig. 4a). However, this station is located north of the Kattegat-Skagerrak front that marks the northern border of the estuarine stratification of the Kattegat, and the salinity of this station was similar to bottom water in the central Kattegat. The deep and shallow stations were significantly different from each other (ANOSIM, $p=0.001$ ). The difference was due to the presence of many rare species and could not be assigned to a few discriminating species. The only truly discriminating species was Amphiura filiformis (Diss/SD = 1.56), which was far more abundant in the deep group (mean: 20.9 ind. per sample) than the shallow group (mean: 5.9 ind. per sample). To test whether the clustering was caused by Amphiura filiformis alone, the species was omitted in the test, but the clustering remained the same. Besides being separated according to depth, the benthic communities showed a distinct and significantly different grouping in relation to the 4 sub-regions of the Kattegat (north, south, east and west; ANOSIM, p = 0.001; Fig. 4b). Only the southern and eastern Kattegat was not significantly different and was combined into a 'southeast' group. The data were separated to see if the lack 

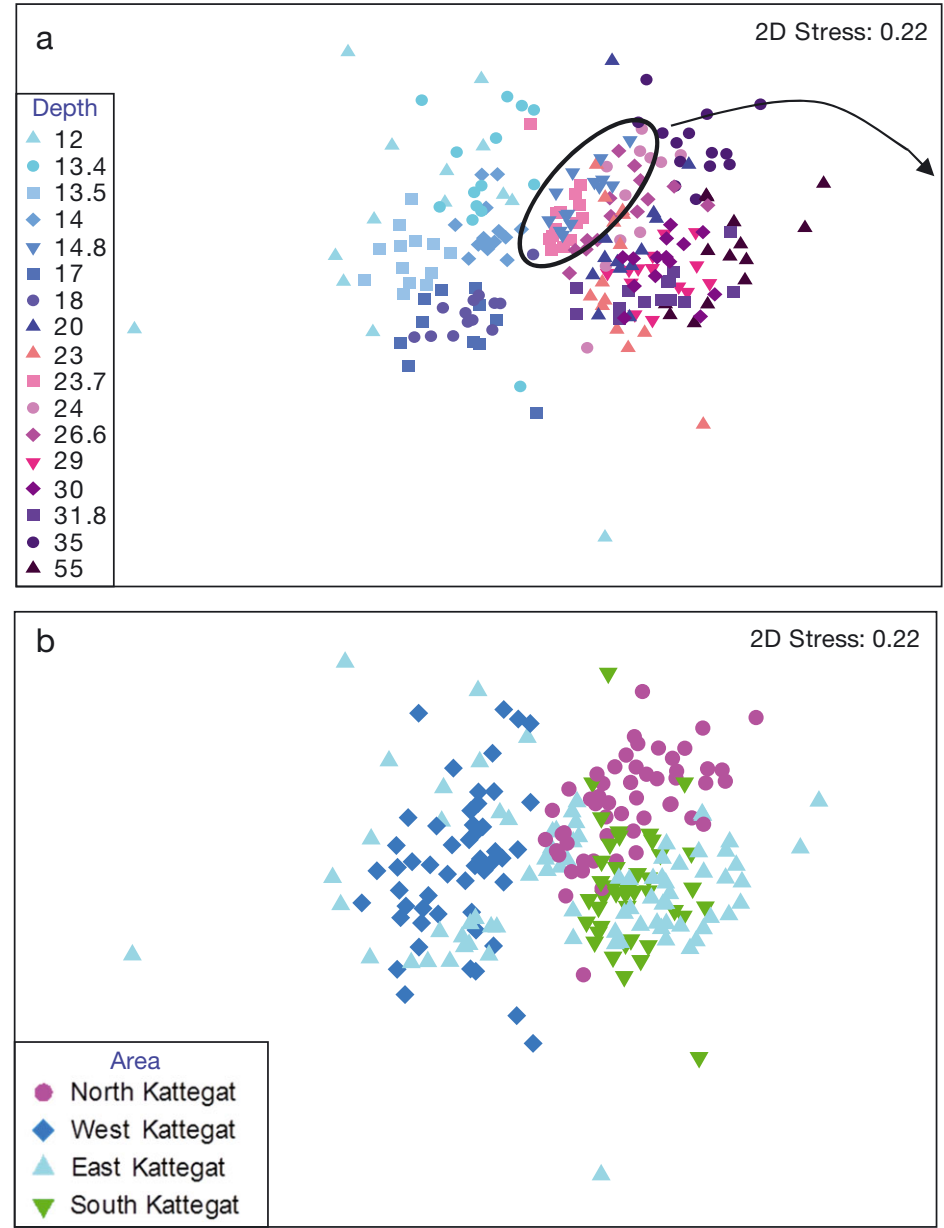

Fig. 4. (a) Similarities among benthic communities in the Kattegat based on (a) sampling depth and (b) sub-regions of the Kattegat. Samples from Danish stations were taken in 1994-2008. Stress value indicates degree of data distortion. The oval in (a) indicates samples from a 'shallow' station (P46), which are more similar to samples from the 'deep' group than the 'shallow' group

\section{Analyses of trawl effects}

The factors that best explained the benthic communities' distribution were depth + salinity, which had a correlation of 0.564 . Depth alone had the second highest correlation (0.471) and depth + salinity + trawl had a correlation of 0.455 . Trawl alone accounted for $\sim 18 \%$ (correlation $=0.179$ ).

Because benthos displayed a general relation to the different Kattegat areas, the potential noise from this relation was removed by analyzing each sub-region of the Kattegat separately. None of the benthic communities in sub-areas north, west and southeast showed differences in similarity along a gradient of trawl disturbance. Thus, there was no significant effect of the magnitude of trawling disturbance in the benthic community assemblages (Fig. 5).

In general, the benthic communities were related to depth, which, in turn, was closely correlated with a salinity gradient, and the clearest difference in community composition was demarcated by the halocline. However, the halocline depth also separated the trawled areas from the nontrawled areas. In addition, the trawl intensity gradient also followed the depth gradient, and all 3 factors (depth, salinity and trawl activity) were so closely intercorrelated that it was not possible to separate the possible effect of the trawl intensity on the benthic communities.

\section{Biological traits}

of discriminating species was caused by noise from the area grouping. Benthic communities in all 4 areas changed with increasing depth and thus repeated the distribution seen for the entire Kattegat data. In the south-eastern group, there was a significant difference between a shallow (only 1 station) and the deep stations (ANOSIM, p = 0.001), and the deep group was also characterized by a large number of low abundant species, with Amphiura filiformis as only typifying species $(\mathrm{Sim} / \mathrm{SD}=2.61)$. Thus, data consistently showed that the community composition in the Kattegat was related to water depth, with a clear segregation of communities above and below the halocline. In addition to the halocline segregation, there seemed to be a continual community change related to depth even in deeper waters.
Comparison of the average abundances of sensitive species from 3 Swedish stations (data from 2000-2008) shows higher (but not significantly higher) abundances of sensitive species at the station with the least trawl activity (Table 2). Only 1 species (Brissopsis lyrifera) was significantly more abundant at the least impacted station than at the 2 more trawled stations. The 2 species Amphiura chiajei and Amphiura filiformis had significantly higher abundances at the low and medium impacted stations compared to the highest impacted station. Furthermore, 2 additional species (Echinocardium cordatum and Virgularia mirabilis) were only found at the low and medium impacted stations, and 2 other species (Haploops tubicola and 

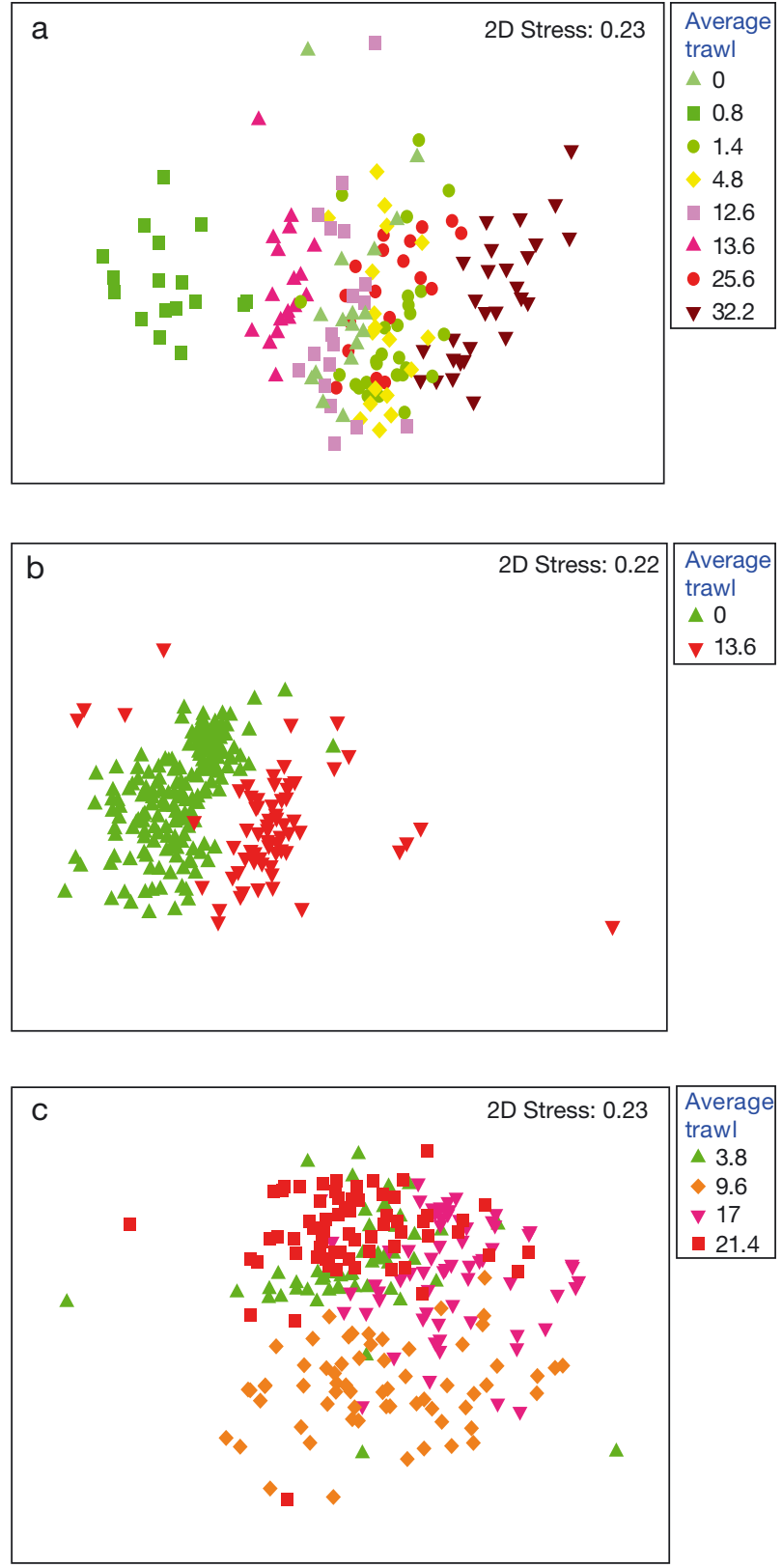

Fig. 5. MDS plots of the similarity between benthic communities (1994-2008) at Danish stations in the 3 distinctive subgroups of the Kattegat area. The colors refer to annual trawl activity at the given station. Green colors indicate low activity and reddish colors indicate high activity. (a) South and eastern sub-region. (b) Western sub-region. (c) Northern sub-region

Cerianthus lloydi) were only found at the least impacted station. The remaining 3 taxa (Aphrodita aculeata, Calocaris macandreae and Edwardsiidae) did not show significant differences related to trawling impact.

\section{DISCUSSION}

\section{Trawl activity}

Since the collapse of the cod fishery in the late 1980 s, the number of vessels and size of catch from trawling has declined dramatically in the Kattegat (The Danish AgriFish Agency 2015). However, in line with previous work (Vitale et al. 2008, Ziegler \& Valentinsson 2008, Hornborg et al. 2012, ICES 2015), this study documents that considerable trawling activity is still occurring, especially in the deeper areas. The VMS data show patchy and highly selective trawling, targeting primarily the eastern deep region as well as the slopes around shallow reefs in the southeast region. Indeed, all habitats in the Kattegat below the halocline and deeper than $22 \mathrm{~m}$ are trawled at least once a year, and the deepest habitats $(>100 \mathrm{~m})$ are subjected to an even higher annual trawl frequency of several trawl incidents per year, in some cases up to 20 events per year. However, in reality, some areas can be free of trawling activity, whereas others will be even more intensively disturbed as the trawl fishery has a patchy distribution (Rijnsdorp et al. 1998). The trawl fishery for $\mathrm{Ne}$ phrops norvegicus will generally avoid rocky areas. However, removal and rearrangement of boulders supposedly caused by physical disturbance from trawl gear have been observed at reefs in the Kattegat (Dahl 2005). As the fishery primarily targets Nephrops norvegicus, whose habitat is muddy sediments where it constructs its burrows (Johnson et al. 2013), it is not surprising that the trawling activity is concentrated in a very well-defined habitat with muddy soft-sediments deeper than $22 \mathrm{~m}$.

Floderus \& Pihl (1990) estimated a higher trawl effort (54 $100 \mathrm{~km}^{2} \mathrm{yr}^{-1}$ ) during 1978-1985 (based on reports from fishermen) than in the present study. Although the calculations are not exactly similar, it is a good indication that trawl fishery has indeed declined in recent decades in the Kattegat. Floderus \& Pihl (1990) defined the area suitable for fishing in the Kattegat to be $5000 \mathrm{~km}^{2}$ and therefore estimated a frequency of almost 11 events per year. Correspondingly, this study suggests 3.4 trawl events per year when using conservative values of gear width in the calculation, and twice that frequency ( 6.8 events per year) when using the total gear width.

Only vessels larger than $15 \mathrm{~m}$ are monitored by the VMS. The proportion of bottom trawl landings from the Kattegat by Danish trawlers larger than $15 \mathrm{~m}$ was approximately $74 \%$ of the total Danish bottom trawl landings for the area during the years 2005-2009 
Table 2. Mean abundance (ind. $\mathrm{m}^{-2} ; \pm 95 \% \mathrm{CI}$ ) of sensitive species at different Swedish stations along a trawl impact gradient: low (4.8 VMS points $\left.\mathrm{yr}^{-1}\right)$, medium (35.4 VMS points $\mathrm{yr}^{-1}$ ) and high (63.8 VMS points $\left.\mathrm{yr}^{-1}\right)$. Bold: highest abundance(s) for each species

\begin{tabular}{|c|c|c|c|c|}
\hline Species & $\begin{array}{l}\text { Biological traits sensitive to } \\
\text { physical disturbance }\end{array}$ & $\begin{array}{l}\text { Low-intensity } \\
\text { trawl }\end{array}$ & $\begin{array}{l}\text { Medium-intensity } \\
\text { trawl }\end{array}$ & $\begin{array}{l}\text { High-intensity } \\
\text { trawl }\end{array}$ \\
\hline Amphiura chiajei & $\begin{array}{l}\text { Position near sediment surface, } \\
\text { slow growth }\end{array}$ & $232.78 \pm 53.37$ & $232.78 \pm 38.72$ & $40.33 \pm 8.88$ \\
\hline Amphiura filiformis & Position near sediment surface & $349.67 \pm 43.26$ & $315.78 \pm 66.90$ & $187.56 \pm 52.76$ \\
\hline Aphrodita aculeata & $\begin{array}{l}\text { Large body size, position near } \\
\text { sediment surface }\end{array}$ & $0.78 \pm 0.84$ & $0.22 \pm 0.34$ & $0.67 \pm 0.67$ \\
\hline Brissopsis lyrifera & $\begin{array}{l}\text { Large body size, late sexual maturity, } \\
\text { slow growth, fragile shell }\end{array}$ & $5.44 \pm 1.49$ & $1.56 \pm 1.02$ & $2.11 \pm 1.05$ \\
\hline Calocaris macandreae & Slow growth, late sexual maturity & $1.78 \pm 2.03$ & $0.22 \pm 0.34$ & $0.56 \pm 0.68$ \\
\hline Cerianthus lloydii & $\begin{array}{l}\text { Large body size, upright and } \\
\text { fragile structure, long lifespan }\end{array}$ & $0.33 \pm 0.54$ & 0 & 0 \\
\hline Echinocardium cordatum & Large body size, slow growth, fragile shell & $0.11 \pm 0.26$ & $0.11 \pm 0.26$ & 0 \\
\hline Edwardsiidae & Upright and fragile structure & $1.11 \pm 1.46$ & $0.11 \pm 0.27$ & $0.67 \pm 1.02$ \\
\hline Haploops tubicola & Tube-building, upright structure & $0.22 \pm 0.26$ & 0 & 0 \\
\hline Virgularia mirabilis & $\begin{array}{l}\text { Large sized colony, sessile, upright } \\
\text { and fragile structure }\end{array}$ & $0.22 \pm 0.34$ & $0.44 \pm 0.41$ & 0 \\
\hline
\end{tabular}

(Table 3). Thus, this study presents a conservative estimate of the trawl activity, and the actual trawl activity is likely higher than that recorded by the satellite surveillance, although it is unclear whether the smaller boats add to the trawl activity in the same types of habitats. The width of the trawl gear is obviously also critical for estimating spatial distribution and impact and, in general, to prevent any overestimation we have used a conservative estimate only considering the impact of the footrope and the trawl doors. The impacts of the bridles and sweeps connecting the nets to the trawl doors are not included, though it has been argued that the entire area will be impacted by turbulence even if the gear does not scrape the surface layer at all times (Jones 1992).

Table 3. Danish landings in the Kattegat from demersal mobile gear by vessels with and without Vessel Monitoring Systems (VMS) for the years 2005 to 2009 (data from Egekvist 2010)

\begin{tabular}{|cccc|}
\hline Year & $\begin{array}{c}\text { Landings } \\
\text { with } \\
\text { VMS (t) }\end{array}$ & $\begin{array}{c}\text { Landings } \\
\text { without } \\
\text { VMS (t) }\end{array}$ & $\begin{array}{c}\text { Proportion landed } \\
\text { with VMS of total } \\
\text { landings (\%) }\end{array}$ \\
\hline 2005 & 20317297 & 6884339 & 75 \\
2006 & 14850690 & 5193796 & 74 \\
2007 & 13615448 & 4506554 & 75 \\
2008 & 8418933 & 2562209 & 77 \\
2009 & 4917377 & 2210546 & 69 \\
\hline
\end{tabular}

\section{Spatial analyses}

Data from satellite surveillance (VMS) offer improved positioning of the geographical distribution of trawl activity and a potential for better studies on the impact of the fishery. However, much still depends on the interpretation of the data. To compare Swedish and Danish trawling in the Kattegat, it was necessary to harmonize the datasets at the expense of spatial resolution. In addition, the data format complicated small scale modelling of trawl distribution between VMS points (Bastardie et al. 2010). The grid was placed and sized according to the Danish data to ensure homogeneous data formats. Another related problem was cells with very low or zero activity appearing within intensively trawled areas. The absence of VMS points in a cell is not evidence of zero trawl activity. As the satellite only receives a signal every hour, there is a chance of 'skipping' cells between recordings. The average speed for active trawling was estimated as $3.7 \mathrm{~km}$ $\mathrm{h}^{-1}$ for Swedish vessels and $5.6 \mathrm{~km} \mathrm{~h}^{-1}$ for the Danish fleet. Since each grid cell is only $1.5 \mathrm{~km}$ wide, the vessels can steam through several cells before being recorded by the satellite. This could lead to false values of zero activity and bias assessment of the trawl effects. Although the data of trawl activity available for this study were good enough for showing overall patterns in the Kattegat, the spatial reso- 
lution was generally too low to assess small-scale trawl distribution. This concerns the way we matched trawl and fauna data. The estimates of trawl activity were assigned to the fauna stations within the respective grid cells, assuming a within-grid cell $\left(2.25 \mathrm{~km}^{2}\right)$ homogeneous distribution. However, trawl distribution could very well be heterogeneous and thereby lead to a wrong trawl estimate at the specific location of the fauna stations. If, for example, bottom topography varies within the grid, then modern GPS equipment enables the trawlers to target specific bottom types within the grid cells, and this will not be reflected in our estimates.

\section{Effects of trawl fishery on benthic communities}

Benthic fauna communities in the Kattegat at depths below $22 \mathrm{~m}$ are distinctively different from more shallow living communities (sensu Petersen 1918). The present study supports conclusions from previous studies (Pearson et al. 1985, Göransson et al. 2010), i.e. that most areas, especially in the deep regions, are strongly dominated by the brittle star Amphiura filiformis and that the deep muddy habitat is very different from the sandier, brackish habitats at more shallow depths (Christiansen et al. 2006), with distinctly different benthic communities (Petersen 1918). Furthermore, the present study documents a continual change of the community composition with increasing depth. Therefore, when the trawl fishery targets a very specific habitat, it also targets a specific faunal community. In the Kattegat, the trawl fishery targets the deep and muddy habitat that may be more vulnerable to trawling because species are probably less adapted to physical disturbance than species in shallow water with frequent physical disturbance, e.g. wave-induced sediment resuspension. Higher productivity in shallow, coastal zones also tends to promote species with rapid growth, whereas the opposite is true for the deeper, less nutrient rich seabed (Pearson \& Rosenberg 1978). In general, species living in deep habitats $(200-600 \mathrm{~m})$ tend to have a slow growth and reach sexual maturity late in their lifespan (Cryer et al. 2002). These biological traits have previously been defined as especially sensitive to physical disturbance, and trawling in faunal communities with these traits should therefore be a cause of concern. With reference to the work of Hiscock \& Tyler-Walters (2006), Nilsson \& Ziegler (2007) argue that the recovery time of the mud habitat in the Kattegat lies between 6 mo and 5 yr. With trawl events generally occurring more than once a year and in some areas up to 20 times annually, the deep mud bottoms of the Kattegat should therefore be considered as chronically disturbed without possibility for recovery as long as the present disturbance level continues.

Multivariate analysis of community compositions could not distinguish between lightly trawled areas and intensively impacted areas. However, the gradient of trawl intensities correlated with environmental gradients of salinity, sediment composition and water depth, which are all factors known to affect and shape benthic soft bottom communities. Apparently, there was a strong habitat selectivity of the trawl activity, meaning that the trawling positively correlated with depth, salinity and sediment mud content. For example, since both benthic communities and trawl fishery were closely correlated with depth, there was almost no variation within a given depth interval for both variables and it was therefore not possible to disentangle trawl effects from the influence of environmental gradients on benthic communities.

The comparisons of biological traits suggest impacts of trawling on sensitive species, even though this effect was not evident in multivariate analysis of the whole faunal community, as described above. Biological trait analysis (Bremner et al. 2003, 2006) and other similar methods (Tillin et al. 2006, de Juan et al. 2007) have proven successful in detecting impacts of bottom trawling on benthic communities elsewhere. Using these approaches, the changes in functional diversity reveal ecological impacts not detected by earlier methods. If human impacts such as trawling pose specific changes to certain physical and chemical properties of a habitat, they can lead to a rapid loss of species with similar ecological functions (Solan et al. 2004). Not only the individual species risk extinction, but, more importantly, also their functional role in the ecosystem. The loss of functional roles within the ecosystem can have far greater effects on a community than declines of single species (Solan et al. 2004). In fact, large-sized bioturbating or bioirrigating animals are especially sensitive to trawl disturbance. These species provide essential ecological services, e.g. increased mineralization rate and ventilation of the sediment, and losing them will affect the quality of the entire ecosystem (Solan et al. 2004, Widdicombe et al. 2004). Further analysis of trawling effects based on biological traits would require inclusion of more traits and species. However, species with sensitive life-history traits are quite rare in this data set, with the exception of the dominating species Amphiura filiformis. To get a better representation of rare species, a larger sampling area is 
needed. Swedish stations were sampled with gear covering a sample area of $0.1 \mathrm{~m}^{2}$, while the Danish stations were all sampled with a Haps corer covering only $0.0143 \mathrm{~m}^{2}$. As a result, large individuals and rare species may not be represented well in the Danish data set, and observations may be too few to detect significant patterns related to trawling.

\section{Reference conditions for trawled habitats}

The low abundances of sensitive species in the study area make studies of trawl effects on faunal communities difficult, even with appropriate sampling gear. Moreover, comparable areas with reference conditions are missing, because the intensive and long-term physical disturbance from trawling activities covers the entire extent of the well-defined muddy habitat in the Kattegat. Therefore, it is not possible to determine how far the faunal community of the impacted area deviates from natural pristine conditions. No suitable reference area has been identified yet, although the neighboring strait, the Sound, could be a possibility. The Sound has similar salinity, temperature and sediment composition, but unlike in the Kattegat, bottom trawling has been banned here since 1932. However, the distance from the Sound to the south-eastern sub-region of the Kattegat is similar to the distances among the respective sub-regions in the Kattegat; because we found significantly different faunal communities in the Kattegat subregions, the community in the Sound may be inherently different, irrespective of trawling activity. Since the hydrography of the Sound also differs from that in the Kattegat, the applicability of the Sound as a reference area is questionable.

Historical data could be an entry into disentangling possible fishery effects from natural gradients in the faunal community. Future studies should focus on using available historical material or further explore the possibility of using the Sound as a contemporary reference site. At the same time, the concept of functional ecology and use of biological trait analysis to show fishery effects hold great promise for better understanding the impacts of bottom trawling on benthic communities.

Acknowledgements. The authors thank the following institutions and employees for their data contributions to the project: Josefine Egekvist, DTU-Aqua, Technical University of Denmark (providing VMS data from the Danish AgriFish Agency); Mattias Sköld, Swedish University of Agricultural Sciences (providing VMS data from the Swedish Board of Fisheries); Ole Manscher, DCE, Aarhus University (provid- ing benthic community data from the Danish National Monitoring Program); Stefan Agrenius, University of Gothenburg (providing benthic community data from the Swedish National Monitoring Program, Naturvårdsverket). We also thank Henrik Gislason (DTU-Aqua, Technical University of Denmark) for valuable comments that helped the writing process and focused important points. The study was supported financially by the European Fisheries Fond and the Ministry for Food, Agriculture and Fisheries of Denmark through 'Økosystembaseret metode til marin konsekvensvurdering af miljømæssige forbedringer', grant no. 3301013-k-0285. The EU-funded project BENTHIS, project no. FP7 KBBE-312088-BENTHIS also supported the study.

\section{LITERATURE CITED}

Aarhus University (2010) Monitoring data on benthic fauna 1979-2008. Aarhus University, Roskilde

Auster PJ, Langton RW (1999) The effects of fishing on fish habitat. In: Benaka L (ed) Fish habitat: essential fish habitat and rehabilitation. American Fisheries Society, Bethesda, MD, Appendix M

Bastardie F, Nielsen JR, Ulrich C, Egekvist J, Degel H (2010) Detailed mapping of fishing effort and landings by coupling fishing logbooks with satellite-recorded vessel geo-location. Fish Res 106:41-53

Blegvad H (1946) Fiskeriet i Danmark. Selskabet til udgivelse af Kulturskrifter, Copenhagen

- Borja A, Franco J, Environment M (2000) A marine biotic index to establish the ecological quality of soft-bottom benthos within European estuarine and coastal environments. Mar Pollut Bull 40:1100-1114

Bradshaw C, Collins P, Brand R (2003) To what extent does upright sessile epifauna affect benthic biodiversity and community composition? Mar Biol 143:783-791

Bradshaw C, Tjensvoll I, Sköld M, Allan IJ and others (2012) Bottom trawling resuspends sediment and releases bioavailable contaminants in a polluted fjord. Environ Pollut 170:232-241

Bray J, Curtis J (1957) An ordination of the upland forest communities of southern Wisconsin. Ecol Monogr 27: 325-349

Bremner J, Rogers SI, Frid CLJ (2003) Assessing functional diversity in marine benthic ecosystems: a comparison of approaches. Mar Ecol Prog Ser 254:11-25

Bremner J, Frid CLJ, Rogers SI (2005) Biological traits of the North Sea benthos: Does fishing affect benthic ecosystem function? In: Barnes PW, Thomas JP (eds) Benthic habitats and the effects of fishing. Proc 41st Am Fish Soc Symp. American Fisheries Society, Bethesda, MD, p 477-489

- Bremner J, Rogers SI, Frid CLJ (2006) Methods for describing ecological functioning of marine benthic assemblages using biological traits analysis (BTA). Ecol Indic 6: 609-622

> Caddy JF (1973) Underwater observations on tracks of dredges and trawls and some effects of dredges on scallop ground. J Fish Res Board Can 30:173-180

Callaway R, Engelhard GH, Dann J, Cotter J, Rumohr H (2007) A century of North Sea epibenthos and trawling: comparison between 1902-1912, 1982-1985 and 2000. Mar Ecol Prog Ser 346:27-43

Christiansen T, Bendtsen J, Gustaffson G (2006) Havets fysiske forhold. In: Fenchel T (ed) Naturen i DanmarkHavet. Gyldendal, Copenhagen, p 49-68 
Clarke KR (1993) Non-parametric multivariate analyses of changes in community structure. Aust J Ecol 18: $117-143$

Clarke KR, Gorley RN (2006) PRIMER v6: user manual/tutorial. PRIMER-E, Plymouth

Collie JS, Escanero GA, Valentine PC (1997) Effects of bottom fishing on the benthic megafauna of Georges Bank. Mar Ecol Prog Ser 155:159-172

Cryer M, Hartill B, O'Shea S (2002) Modification of marine benthos by trawling: toward a generalization for the deep ocean? Ecol Appl 12:1824-1839

Dahl K (2005) Effekter af fiskeri på stenrevs algevegetation. Et pilotprojekt på Store Middelgrund i Kattegat. Danmarks Miljøundersøgelser (DMU), Roskilde

> Dayton PK, Tegner MJ, Edwards PB, Riser KL (1998) Sliding baselines, ghosts and reduced expectations in kelp forest communities. Ecol Appl 8:309-322

de Groot SJ (1984) The impact of bottom trawling on benthic fauna of the North Sea. Ocean Manag 9:177-190

$>$ de Juan S, Thrush SF, Demestre M (2007) Functional changes as indicators of trawling disturbance on a benthic community located in a fishing ground (NW Mediterranean Sea). Mar Ecol Prog Ser 334:117-129

de Juan S, Demestre M, Thrush SF (2009) Defining ecological indicators of trawling disturbance when everywhere that can be fished is fished: a Mediterranean case study. Mar Policy 33:472-478

DTU-Aqua (2010) GIS files of fishing effort based on VMS records. Audiovisual material. DTU-Aqua, Charlottenlund

Egekvist J (2010) Table of landings in Kattegat from 2005 to 2009 with and without VMS. DTU-Aqua, Charlottenlund

> Eigaard OR, Bastardie F, Breen M, Dinesen GE and others (2016) Estimating seafloor pressure from demersal trawls, seines and dredges based on gear design and dimensions. ICES J Mar Sci 73(Suppl 1):i27-i43

ESRI (Environmental Systems Research Institute) (2009) ArgGIS Desktop: Release 9.3. ESRI, Redlands, CA

Floderus S, Pihl L (1990) Resuspension in the Kattegat: impact of variation in wind climate and fishery. Estuar Coast Shelf Sci 31:487-498

Göransson P, Vuksan SB, Karlfelt J, Börjesson L (2010) Haploops- och Modiolus-samhället utanför Helsingborg 2000-2009. Miljönämnden, Helsingborg

> Greathead CF, Donnan DW, Mair JM, Saunders GR (2007) The sea pens Virgularia mirabilis, Pennatula phosphorea and Funiculina quadrangularis: distribution and conservation issues in Scottish waters. J Mar Biol Assoc UK 87: 1095-1103

Griffin JN, Jenkins SR, Gamfeldt L, Jones D, Hawkins SJ, Thompson RC (2009) Spatial heterogeneity increases the importance of species richness for an ecosystem process. Oikos 118:1335-1342

Groenewold S, Fonds M (2000) Effects on benthic scavengers of discards and damaged benthos produced by the beam-trawl fishery in the southern North Sea. ICES J Mar Sci 57:1395-1406

Hall SJ (1994) Physical disturbance and marine benthic communities - life in unconsolidated sediments. Oceanogr Mar Biol Annu Rev 32:179-239

> Handley SJ, Willis TJ, Cole RG, Bradley A, Cairney DJ, Brown SN, Carter ME (2014) The importance of benchmarking habitat structure and composition for understanding the extent of fishing impacts in soft sediment ecosystems. J Sea Res 86:58-68
Henriksen P, Møller EF, Dahl K, Stæhr P and others (2012) Karakterisering af de biologiske forhold i de danske havområder. Aarhus University, Danish Centre for Environment and Energy, Silkeborg, p 97

> Hewitt JE, Thrush SF, Halliday J, Duffy C (2005) The importance of small-scale habitat structure for maintaining beta diversity. Ecology 86:1619-1626

- Hiddink JG, Jennings S, Kaiser MJ, Queirós AM, Duplisea DE, Piet GJ (2006) Cumulative impacts of seabed trawl disturbance on benthic biomass, production, and species richness in different habitats. Can J Fish Aquat Sci 63: 721-736

Hinz H, Prieto V, Kaiser MJ (2009) Trawl disturbance on benthic communities: chronic effects and experimental predictions. Ecol Appl 19:761-773

Hiscock K, Tyler-Walters H (2006) Assessing the sensitivity of seabed species and biotopes - the Marine Life Information Network. Hydrobiologia 555:309-320

> Hixon MA, Tissot BN (2007) Comparison of trawled vs untrawled mud seafloor assemblages of fishes and macroinvertebrates at Coquille Bank, Oregon. J Exp Mar Biol Ecol 344:23-34

> Hornborg S, Nilsson P, Valentinsson D, Ziegler F (2012) Integrated environmental assessment of fisheries management: Swedish Nephrops trawl fisheries evaluated using a life cycle approach. Mar Policy 36:1193-1201

Huston MA (1998) Biological diversity: the coexistence of species. Cambridge University Press, Cambridge

ICES (International Council for the Exploration of the Sea) (2015) Report of the Working Group for the Assessment of Demersal Stocks in the North Sea and Skagerrak (WGNSSK). ICES CM 2014/ACOM:13. ICES, Copenhagen

ICES (2011) Annex 3-Stock annex-Kattegat cod. In: ICES WGBFAS report 2011, p 512-529

> Johnson AF, Gorelli G, Jenkins SR, Hiddink JG, Hinz H, Johnson AF (2015) Effects of bottom trawling on fish foraging and feeding. Proc R Soc B 282:20142336

Johnson MP, Lordan C, Power AM (2013) Habitat and ecology of Nephrops norvegicus. Adv Mar Biol 64:27-63

Jones JB (1992) Environmental impact of trawling on the seabed: a review. NZ J Mar Freshw Res 26:59-67

Kaiser MJ, Spencer BE (1996) The effects of beam-trawl disturbance on infaunal communities in different habitats. J Anim Ecol 65:348-358

Kaiser MJ, Collie JS, Hall SJ, Jennings S, Poiner IR (2002) Modification of marine habitats by trawling activities: prognosis and solutions. Fish Fish 3:114-136

Kaiser MJ, Clarke KR, Hinz H, Austen MCV, Somerfield PJ, Karakassis I (2006) Global analysis of response and recovery of benthic biota to fishing. Mar Ecol Prog Ser 311:1-14

Kaitaranta J, Reker J, Al-Hamdani Z (2008) Marine seabed sediments in the Baltic Sea (BALANCE). Helsinki Commission, Helsinki (http://helcom.fi/baltic-sea-trends/ data-maps/biodiversity/balance

Kanneworff E, Nicolaisen W (1972) The 'Haps' — a frame supported bottom corer. Ophelia 10:119-129

Leth JO, Lomholt S, Al-Hamdani Z, Jensen JB and others (2015) Seabed sediments in Danish waters. Geological Survey of Denmark and Greenland (GEUS). Audiovisual material. GEUS, Copenhagen

> Mangano MC, Kaiser MJ, Porporato EMD, Lambert GI, Rinelli P, Spanò N (2014) Infaunal community responses to a gradient of trawling disturbance and a long-term 
Fishery Exclusion Zone in the Southern Tyrrhenian Sea. Cont Shelf Res 76:25-35

Naturvårdsverket (2010) Monitoring data of benthic fauna in Kattegat 2000-2008. Swedish National monitoring programme in Kattegat, Stockholm

Nilsson P, Ziegler F (2007) Spatial distribution of fishing effort in relation to seafloor habitats in the Kattegat, a GIS analysis. Aquat Conserv 17:421-440

Norse EA, Watling L (1999) Impacts of mobile fishing gear: the biodiversity perspective. Am Fish Soc Symp 22:31-40

Olsgard F, Schaanning MT, Widdicombe S, Kendall MA, Austen MC (2008) Effects of bottom trawling on ecosystem functioning. J Exp Mar Biol Ecol 366:123-133

Paulomäki H, Pyhälä M, Reker J, Al-Hammdani Z (2008) Marine seabed sediments in the Baltic Sea. Audiovisual material. Helsinki Commission, Helsinki

Pearson TH, Rosenberg R (1978) Macrobenthic succession in relation to organic enrichment and pollution of the marine environment. Oceanogr Mar Biol Annu Rev 16: $229-231$

Pearson TH, Josefson AB, Rosenberg R (1985) Petersen's benthic stations revisited-Is the Kattegat becoming eutrophic? J Exp Mar Biol Ecol 92:157-206

Petersen CGJ (1918) Havets Bonitering II: Om Havbundens Dyresamfund og disses Betydning for den marine Zoogeografi. Fra den danske biologiske Station, XXI. Geol Foren Stockh Forh 40:888-891

Ramsay K, Kaiser MJ, Hughes RN (1998) Responses of benthic scavengers to fishing disturbance by towed gears in different habitats. J Exp Mar Biol Ecol 224:73-89

Rijnsdorp AD, Buys AM, Storbeck F, Visser EG (1998) Micro-scale distribution of beam trawl effort in the southern North Sea between 1993 and 1996 in relation to the trawling frequency of the sea bed and the impact on benthic organisms. ICES J Mar Sci 55:403-419

Robinson LA, Frid CLJ (2008) Historical marine ecology: examining the role of fisheries in changes in North Sea benthos. Ambio 37:362-371

Rosenberg R, Cato I, Förlin L, Grip K, Rodhe J (1996) Marine environment quality assessment of the Skagerrak-Kattegat. J Sea Res 35:1-8

Rosenberg R, Nilsson HC, Grémare A, Amouroux JM (2003) Effects of demersal trawling on marine sedimentary habitats analysed by sediment profile imagery. J Exp Mar Biol Ecol 285-286:465-477

Rumohr H, Krost P (1991) Experimental evidence of damage to benthos by bottom trawling, with special reference to Arctica islandica. Helgol Meeresunters 33:340-345

Rumohr H, Kujawski T (2000) The impact of trawl fishery on the epifauna of the southern North Sea. ICES J Mar Sci $57: 1389-1394$

Solan M, Cardinale BJ, Downing AL, Engelhardt KAM, Ruesink JL, Srivastava DS (2004) Extinction and ecosystem function in the marine benthos. Science 306 : $1177-1180$

Svedäng H (2010) Long-term impact of different fishing methods on the ecosystem in the Kattegat and Øresund.

Editorial responsibility: Charles Peterson,

Morehead City, North Carolina, USA
The European Parliament's Committee on Fisheries, Brussels

Swedish Board of Fisheries (2010) GIS-files of fishing effort based on VMS records. Audiovisual material. Swedish Board of Fisheries, Lysekil

The Danish AgriFish Agency (2015) Landing and catch statistics. Available at http://naturerhverv.dk/fiskeri/ fiskeristatistik/landings-og-fangststatistik/\#c8901 (accessed 24 Apr 2015)

Thrush SF, Dayton PK (2002) Disturbance to marine benthic habitats by trawling and dredging: implications for marine biodiversity. Annu Rev Ecol Syst 33:449-473

- Thrush SF, Hewitt JE, Cummings VJ, Dayton PK and others (1998) Disturbance of the marine benthic habitat by commercial fishing : impacts at the scale of the fishery. Ecol Appl 8:866-879

Thrush SF, Gray JS, Hewitt JE, Ugland KI (2006) Predicting the effects of habitat homogenization on marine biodiversity. Ecol Appl 16:1636-1642

> Tillin HM, Hiddink JG, Jennings S, Kaiser MJ (2006) Chronic bottom trawling alters the functional composition of benthic invertebrate communities on a sea-basin scale. Mar Ecol Prog Ser 318:31-45

van Denderen PD, Hintzen NT, Rijnsdorp AD, Ruardij P, van Kooten T (2014) Habitat-specific effects of fishing disturbance on benthic species richness in marine soft sediments. Ecosystems 17:1216-1226

> Vitale F, Börjesson P, Svedäng H, Casini M (2008) The spatial distribution of cod (Gadus morhua L.) spawning grounds in the Kattegat, eastern North Sea. Fish Res 90: $36-44$

Watling L, Norse EA (1998) Disturbance of the seabed by mobile fishing gear: a comparison to forest clearcutting. Conserv Biol 12:1180-1197

> Widdicombe S, Austen MC (1998) Experimental evidence for the role of Brissopsis lyrifera (Forbes, 1841) as a critical species in the maintenance of benthic diversity and the modification of sediment chemistry. J Exp Mar Biol Ecol 228:241-255

> Widdicombe S, Austen MC, Kendall MA, Olsgard F, Schaanning MT, Dashfield SL, Needham HR (2004) Importance of bioturbators for biodiversity maintenance: indirect effects of fishing disturbance. Mar Ecol Prog Ser 275:1-10

> Wilding TA (2011) A characterization and sensitivity analysis of the benthic biotopes around Scottish salmon farms with a focus on the sea pen Pennatula phosphorea L. Aquacult Res 42:35-40

Ziegler F, Valentinsson D (2008) Environmental life cycle assessment of Norway lobster (Nephrops norvegicus) caught along the Swedish west coast by creels and conventional trawls - LCA methodology with case study. Int J Life Cycle Assess 13:487-497

Ziegler F, Nilsson P, Mattsson B, Wahher Y (2003) Life cycle assessment of frozen cod fillets including fishery-specific environmental impacts. Int J Life Cycle Assess 8:39-47

Submitted: May 21, 2015; Accepted: February 2, 2016

Proofs received from author(s): April 12, 2016 